\title{
Social Network Marketing Strategy and SME Strategy Benefits
}

\author{
HELENA NOBRE \\ University of Aveiro, Aveiro, Portugal and iMarke, Research in Marketing and Strategy, \\ Braga, Portugal \\ DANIELA SILVA \\ University of Minho, Braga, Portugal
}

\begin{abstract}
The study explored what benefits to small or medium-sized firms (SMEs) could be derived from the development of a social media marketing strategy. Results indicated that Facebook can facilitate communications between SME companies and customers, and can also be an important tool in creating brand recognition and broadening awareness. The importance of developing a thoughtfully designed strategy was cited, as SMEs often lack sopbisticated marketing or business plans. The positive study results suggest that SMEs can derive benefits from a SN (social network) strategy and, in particular, Facebook was shown to be an important channel that enabled small and medium-sized companies to advertise their brands without requiring large budgets. Facebook presents itself as a unique environment that can enable businesses to increase prospective clients and also offer current consumers a closer relationship to the company. As such, the study indicated that presence on social networks can have an important role in both relationship development and increased sales/membership.
\end{abstract}

KEYWORDS Facebook, small medium companies, SME, social networks, strategy

While the need for a social network (SN) marketing strategy has been explored with large firms, little exploration has been undertaken to 
determine their usefulness to small ( $<50$ employees and 10 million in sales) or medium ( $<250$ employees and 50 million in sales) enterprises (SMEs). The intent of this study was to examine the potential benefits to an SME that could be derived from a social network strategy.

The importance of a social network strategy for a small or medium-sized firm emanates from the explosion of online social networks that allow information to be disseminated in different ways and sociability to take new directions. An additional significant benefit to the SME is the relatively inexpensive cost of a relatively sophisticated SN strategy that connects the firm directly to current and potential consumers. Social network sites provide a way to be closer to consumers with the added benefit of not needing to go through "'gate keepers"' to transmit information, having the ability to communicate in an easy and accessible way (Hennig-Thurau et al., 2010).

There are several important online social networks where millions of users interact daily. Facebook, Twitter, and Kurkut are among the most widely used. The study focused on Facebook, with 90 million members, due to its heavy European influence as well as its importance in Portugal where the study was conducted. Currently, there are 4,644,220 Facebook users in the Portugal, which makes it number 39 in the ranking of all Facebook statistics by country. Facebook penetration in Portugal is $43 \%$ in relation to population and $85 \%$ in relation to Internet users. The largest age group is currently $25-34$ with 1,214,920 users, followed by users aged 18-24. Meanwhile, $51 \%$ of the Facebook users are male and $49 \%$ are female (Social Backers, 2013). Perhaps one reason for Facebook's popularity is that Facebook, compared to LinkedIn and ASmallWorld, offers the most comprehensive tools for personalization and a larger management of the profile on the network (Papacharissi, 2009).

Companies recognize that social networks represent a new way to communicate with consumers, allowing a company to extend its communications, develop a reputation, and promote firm image (Becker, Nobre, \& Vijay, 2013). It would seem natural then that firms would look to this channel to promote their brands, communicate with customers, and increase sales (Burson-Marsteller, 2010).

The importance of $\mathrm{SN}$ is well stated by Facebook promotional materials, which point the benefits to firms that use their platform. Stressing the importance of WOM (word-of-mouth) marketing, the Facebook site notes the following benefits of using Facebook in social network strategy (Facebook, 2013).

1. Customized news feed based on users' personal information and interactions, which indicates what they may like.

2. Brand recognition means that you stand on a huge public platform, where every eye can be focused on you, resulting in image building of your brand or service. 
3. Facebook fan box is a persuasive tool through which e-mail recipients or website visitors can easily become your fan and follow your business page.

4. Effective brand monitoring allows the firm to counter misconceptions or negative comments or opinions about your company by directly addressing them.

5. Increase search engine rankings because all data can be made public so by using major brand key words a company page can come up on top on Google or Yahoo search engines.

Social networks appear to be an exceptional tool for companies to communicate with consumers due to the speed with which information circulates and the low costs associated compared to traditional marketing. Of particular importance to a firm is the ease of consumer feedback. Focus groups are becoming a tool of the past as firms with solid consumer recognition can solicit information directly from hundreds of interested Facebook fans. The power of social media lies in its viral nature, so it is one consumer relating to another that quickly spreads the marketing message throughout the Internet. While WOM can work against the brand in a negative way, a carefully monitored SN strategy is amply justified (Becker, Nobre, \& Vijay, 2013).

Although the nature of SNs is dramatic, the preponderance of research still focuses on the more traditional marketing concepts. Gil-Or (2010) states that in the area of online social networks, particularly in Facebook, there is little academic research related to marketing and business. In this sense, to study how companies work their image, communication, and relationship management, specifically in the context of Facebook, provides an important contribution. This is even truer in the case of small and medium-sized firms. It is also important to recognize how social network strategy can be used in small nations, as most research tends to focus on North America or the more industrialized nations of Europe, such as the UK and Germany. The purpose of the study was to explore how SMEs are using social networks in a small, less-developed nation (Portugal) to determine what lessons could be ascertained for other similar nations and firms of similar size. To this end, the study addressed three questions:

1. Do social networks have an impact in management strategy for small medium Portuguese enterprises?

2. Does a company's presence on a social network help improve communication with the firms' current and/or potential consumers?

3. Will a presence have a positive impact on the relationship that the consumer establishes with the firm/brand?

In the process of online communication WOM plays a central role in the dissemination of new products and services where their intangibility makes 
sharing the experience even more important to consumers (Gil-Or, 2010). Brown and Reingen (1987) further reinforce the crucial role WOM plays in consumer attitudes and behaviors.

WOM is a very prominent communication tool on the Internet; this presents itself as a privileged means for consumers to share their opinions, as well as preferences and experiences (Trusov, Bucklin, \& Pauwels, 2009). Graham and Havlena (2007) contend that the interest in the power of WOM can be traced to the advent of the Internet, which facilitated the sharing of information from consumer to consumer regardless of time or location. They argue that the online opinions of consumers can be long lasting and far reaching, demonstrating effects on purchase choice. Hyllegard, Ogle, Yan, and Reitz (2011) also emphasize that consumers seem to rely more on the opinions expressed in social media than in the information generated and shared by companies themselves. Based on these ideas the following hypothesis was formulated.

\section{H1: Small medium enterprises will benefit from the impact of WOM on social networks.}

It is clear that Facebook provides a company with a unique opportunity to communicate with a collection of consumers who have a personal interest in the company's products and brand. With this knowledge, Facebook can contribute to better understanding of the product and the sharing of experiences related to satisfaction or dissatisfaction with the product (Hyllegard et al., 2011). Facebook also allows for greater social activity between users and simultaneously helps businesses through direct dialogue to interact with existing and/or potential customers (Deloitte, 2012). Through social networking WOM consumers can share their experiences with the products in a unique way (Soares, Pinho, \& Nombre, 2012). The importance of $\mathrm{SN}$ in discussing products and services led to the following hypothesis.

\section{H2: Social networks are an important means of enabling consumers to share information about a product/service.}

Soares et al. (2012) state that for consumers to decide to communicate with companies they must feel comfortable with sharing personal information and free to provide direct company/product comments. Kaplan and Haenlein (2010) also corroborate this idea, arguing that companies must deliver their message in a coherent and consistent way. Reinartz, Krafft, and Hoyer (2004) conceptualize Customer Relationship Management (CRM) at the client level and believe there are three stages of relationship developed with the customer (initiation, maintenance, and end). It is important that firms recognize, in their communication, which stage the customer represents.

Gil-Or (2010, p. 22) states that "in order to build the level of trust and transparency that is needed for the consumers to feel comfortable with 
companies participating in what is considered a not commercial environment (such as Facebook), companies should invest in doing Relationship marketing right." When this is accomplished McKeefery (2008) states that social networks such as Facebook can provide a powerful presence for the firm, which according to Zhang (2010) can serve to build strong relationships between potential and current consumers. Based on this assumption a third hypothesis was formulated.

\section{H3: The level of communication in social networks reflects the quality of the relationship that companies have with consumers.}

In a study conducted by Deloitte (2012), Facebook was found to enable companies to focus advertising toward a specific group of user once the site visitors had become fans of the firm. Through monitoring the communication between consumers and engaging visitors, companies are able to promote the brand where it is most effective and meaningful in order to generate awareness and new sales. According to Urde (1999) a brand is inseparable from the company, so the effective use of brand sites can create an environment where personal interactions about a product/service can result in increased brand value. Social network sites can be effective in developing personal relationships with the firm/brand, which can serve to assist consumers to identify with the brand, thus making it different from others and, at the same time, help the company to differentiate itself from the competition (Grönroos, 2001).

Familiarity with the brand happens when the consumer formulates favorable, strong, and unique brand associations (Keller, 1993). These build brand image and, simultaneously, the construction of value. Social networks are an important channel in the management of the company's reputation, which for this discussion could be equated to brand value (Becker et al., 2013). This leads to the following hypothesis.

\section{H4: The presence of small medium enterprises in social networks will have a direct impact on the brand familiarity of these firms to the consumer.}

If the consumer is satisfied there are more chances to be loyal or engage with the brand and buy it whenever needed (Bloemer \& Kasper, 1994).

A study by Deloitte (2012) determined that a company's Facebook page can increase knowledge about the brand and about the company's activities, enabling the company to interact through direct dialogue with existing or potential consumers and can promote the firm's links to company websites. By increasing traffic on the company website, Facebook has been responsible for helping increase sales. Facebook offers a firm the ability to advertise to a particular consumer group focusing messages that meet their specific needs and tastes (Deloitte, 2012). In addition, the less formal communication format allows the company to connect with consumers and "tell a story" 
about the identity of the brand or product, thus helping to convert customers into loyal advocates of the company (Burson-Marsteller, 2010). This led to the final hypothesis.

\section{H5: The direct contact with consumers through social networks generates greater involvement, resulting in $s$ a direct impact on brand loyalty intentions.}

Virtual brand communities in social network sites have received increasing attention from both academia and industry. A study of 333 virtual brand community members in Korean social network sites suggests that members of brand communities have six primary social and psychological motives for engaging in virtual community activities: interpersonal utility, brand loyalty, entertainment seeking, information seeking, incentive seeking, and convenience seeking. Among them, brand loyalty acts like the facilitator who sets up an essential connection between real world and the intangible cyber network. It was noted that members of consumer versus marketer-generated brand communities had both similarities as well as differences in terms of the extent of community participation and the levels of community commitment, satisfaction, and future intention (Sunga, Kima, Kwona, \& Moona, 2010).

\section{METHODOLOGY}

A qualitative approach was chosen as the best method since this methodology appears when there is a "need to get meaning and in depth" (Carson, Gilmore, Perry, \& Gronhaug, 2001, p. 69). According to Neale, Thapa, and Boyce (2006) one of the main advantages of studying the case is that this method enables access to more detailed information compared to other methods, therefore providing "a more complete picture" of what happened in that particular "context, and why."

The use of social networks as a management tool, particularly for small medium enterprises, is a recent development and scientific literature remains scarce (Gil-Or, 2010). Yin (1994) states that the exploratory multiple-case study is an appropriate, and perhaps the best method when undertaking this type of investigation. The multi-case analysis has several advantages as multiple firms can indicate trends and offer insights that a single case study is not capable of doing. Herriott and Firestone add that "evidence from multiple cases are considered more compelling and comprehensive... being being more robust" (Herriott \& Firestone, 1983, cited in Yin, 2001, p. 68) the study offered greater support for generalization as the four companies represented different business sectors.

Yin (1994) notes that the case study fits in the investigation when a "'how' or 'why' question is being asked about a contemporary set of events 
over which the investigator has little or no control" (Yin, 1994, p. 9). Building on this, the researchers believe that the multi-case method is well suited for and can be applied to investigations that have an initial exploratory hypotheses that can be studied and developed to provide future insights into broader research activities. The research was designed to investigate how social networks impact the strategy of small medium Portuguese enterprises. The format was to analyze four cases using semi-structured interviews, and later on elaborating a "cross-company case" where each company was analyzed and compared to ascertain the expectation of patterns relating to either social network strategic designs or outcomes.

Four small medium Portuguese enterprises were selected based on four specific criteria:

1. companies had to be present on Facebook;

2. companies had more than 250 "likes" on their pages;

3. were selected companies that operated in different areas, two of which offer products and the rest falls in the services area; and

4. the geographical location of firmsall located in the northern region of the country, in order to give facility and access to company managers to be interviewed.

Consistent with the exploratory nature of the study, the collection of data was made by semi-structured management interviews.

A detailed script was divided in three parts: (1) the reasons that led the company to be present on Facebook; (2) the way management is implemented in Facebook, and (3) the advantages that the company derived from its presence on Facebook. In addition, secondary data was obtained from the company managers/directors.

\section{THE EMPIRICAL STUDY}

Four SME Portuguese enterprises were selected for the multi-case study: ACIAB, Braga Pop Hostel; Brb. Artesanato Urbano (Brb. Urban Craft), and MARKA-Vinhos do Douro (Table 1).

The $A C I A B$ is a business association, founded in 1911, and its goal is to promote business development in the region providing assistance to firms to adapt in the current market as well as providing tools to compete and innovate. $\mathrm{ACIAB}$ has more than 1,000 associates (companies) in different branches of business, from trade, industry, and services.

Braga POP Hostel is the first hostel in the city of Braga, in an early differentiating aspect of the brand, and desires to position itself as a local informal housing alternative that is close to the customer and youth culture. 
TABLE 1 Description of Companies Studied

\begin{tabular}{|c|c|c|c|c|}
\hline & $\mathrm{ACIAB}$ & $\begin{array}{c}\text { Braga Pop } \\
\text { Hostel }\end{array}$ & $\begin{array}{c}\text { Brb. Artesanato } \\
\text { Urbano }\end{array}$ & $\begin{array}{c}\text { MARKA-Vinhos } \\
\text { do Douro }\end{array}$ \\
\hline Location & $\begin{array}{l}\text { Arcos de } \\
\text { Valdevez/ } \\
\text { Ponte da Barca }\end{array}$ & Braga & Viana do Castelo & Porto \\
\hline Business Activity & $\begin{array}{l}\text { Economic } \\
\text { Organization }\end{array}$ & $\begin{array}{l}\text { Local hosting } \\
\text { of short } \\
\text { duration }\end{array}$ & $\begin{array}{l}\text { Manufacture and } \\
\text { sale of jewelry } \\
\text { (craft) }\end{array}$ & $\begin{array}{l}\text { Production of } \\
\text { wines }\end{array}$ \\
\hline Product Type & $\begin{array}{c}\text { Intangible, } \\
\text { durable }\end{array}$ & $\begin{array}{l}\text { Intangible, not } \\
\text { durable }\end{array}$ & $\begin{array}{l}\text { Tangible, } \\
\text { durable }\end{array}$ & $\begin{array}{l}\text { Tangible, } \\
\text { perishable }\end{array}$ \\
\hline $\begin{array}{l}\text { Beginning of } \\
\text { Activity }\end{array}$ & 1911 & 2011 & 2006 & 1991 \\
\hline $\begin{array}{l}\text { Initial Presence } \\
\text { on Facebook }\end{array}$ & May 2010 & July 2011 & May 2010 & April 2010 \\
\hline $\begin{array}{l}\text { Number of fans } \\
\text { on Facebook } \\
\text { page: March } \\
2012\end{array}$ & 256 & 714 & 1.308 & 5.721 \\
\hline $\begin{array}{l}\text { Number of friends } \\
\text { on Facebook } \\
\text { profile page: } \\
\text { March } 2012\end{array}$ & 4.899 & 1.259 & 610 & $\begin{array}{l}\text { It has no } \\
\text { profile page }\end{array}$ \\
\hline
\end{tabular}

Brb. Urban Craft produces an urban crafts adapted to constantly changing consumer habits and their search for something unique. Creativity and innovation are the hallmarks of the company as well as environmental concerns, having a clear careful selection of materials used in the various manufactured parts.

Durham Agrellos Wines S.A. was founded in 1991 but the name "MARKA" appeared only in 2004. This was at the time of the introduction of the wine "Doc Reserva 2002". MARKA markets an extensive range of wines including, red, white, and classic blends, and has received several medals in European competitions.

All the selected cases are from the north of Portugal, for the data collection facility. Companies have a philosophy of being proactive; that is, despite being very small and not having extensive resources, they adapted themselves to the circumstances and got into the market with a clear vision of what they represent and how they intend to place regarding the competition. These companies are concerned about their brands.

All firms are active Facebook sites, which allows them to communicate to a large number of individuals. Membership is simple, requiring only user registration and an Internet connection.

The cases of the research are summarized in Table 1. 
TABLE 2 Purpose of Company Facebook Page

\begin{tabular}{lcccc}
\hline & ACIAB & $\begin{array}{c}\text { Braga Pop } \\
\text { Hostel }\end{array}$ & $\begin{array}{c}\text { Brb. Urban } \\
\text { Craft }\end{array}$ & $\begin{array}{c}\text { Douro } \\
\text { Wines }\end{array}$ \\
\hline $\begin{array}{l}\text { Expand awareness by WOM } \\
\text { Share information about the company }\end{array}$ & $\mathrm{X}$ & & & \\
Greater coverage of consumers at territorial level & $\mathrm{X}$ & $\mathrm{X}$ & $\mathrm{X}$ & $\mathrm{X}$ \\
Manage negative WOM impacts & & & $\mathrm{X}$ & $\mathrm{X}$ \\
\hline
\end{tabular}

\section{RESULTS}

Managers had different aspirations for their Facebook page (Table 2). Only one desired to have the site expand the number of interested viewers (ACIAB). This is an understandable goal for them, being an association membership-based company. Two firms of the four expressed a desire to mitigate the effects of negative WOM comments on the site. Although the international aspects of the Internet and Facebook are widely discussed, it is interesting that all firms desired viewers to share information about their company and to obtain a greater fan base from the local area.

The first aspect is reflected in how WOM appears in Facebook; in the four cases, the site seems to present itself as a means of fostering the sharing of information about the company and a wider range of consumers' territorial level as well, because the companies have visitors from various parts of the world.

The purpose of the company Facebook page varied among the firms. The firm ACIAB had a different outcome objective than the others, being a not-fo- profit organization whose goal was not revenue based but rather to assist firms in the region through seminars and consulting. As such, it was the only firm with the objective of creating a viral environment to spread information among members about organization operations. All firms shared

TABLE 3 Objectives of Company Facebook Page

\begin{tabular}{lcccr}
\hline & ACIAB & $\begin{array}{c}\text { Braga Pop } \\
\text { Hostel }\end{array}$ & $\begin{array}{c}\text { Brb. Urban } \\
\text { Craft }\end{array}$ & $\begin{array}{r}\text { Douro } \\
\text { Wines }\end{array}$ \\
\hline $\begin{array}{l}\text { The importance of formulating questions } \\
\text { and exchanging dialogue with consumers }\end{array}$ & $\mathrm{X}$ & $\mathrm{X}$ & $\mathrm{X}$ & $\mathrm{X}$ \\
$\begin{array}{c}\text { Act as a channel framed in the } \\
\text { communication strategy of the company }\end{array}$ & $\mathrm{X}$ & $\mathrm{X}$ & $\mathrm{X}$ & $\mathrm{X}$ \\
$\begin{array}{l}\text { Importance in organization and promotion } \\
\text { of company events }\end{array}$ & $\mathrm{X}$ & & $\mathrm{X}$ & $\mathrm{X}$ \\
$\begin{array}{c}\text { To assist in understanding the consumer } \\
\text { profile }\end{array}$ & $\mathrm{X}$ & & & \\
$\begin{array}{l}\text { Importance in consumer relationship } \\
\text { management }\end{array}$ & $\mathrm{X}$ & & \\
\hline
\end{tabular}


TABLE 4 Benefits the Company Reported as a Result of Their Facebook Page

\begin{tabular}{lcccc}
\hline & ACIAB & $\begin{array}{c}\text { Braga Pop } \\
\text { Hostel }\end{array}$ & $\begin{array}{c}\text { Brb. Urban } \\
\text { Craft }\end{array}$ & $\begin{array}{c}\text { Douro } \\
\text { Wines }\end{array}$ \\
\hline Increased knowledge about this company & $\mathrm{X}$ & & $\mathrm{X}$ & $\mathrm{X}$ \\
Increased traffic on the company website & $\mathrm{X}$ & $\mathrm{X}$ & $\mathrm{X}$ & $\mathrm{X}$ \\
Increased traffic on the company's Facebook page & $\mathrm{X}$ & $\mathrm{X}$ & $\mathrm{X}$ & \\
Increased number of clients & & $\mathrm{X}$ & $\mathrm{X}$ & $\mathrm{X}$ \\
Act as a channel for brand loyalty & & & $\mathrm{X}$ \\
Increased the sales volume
\end{tabular}

the objectives of sharing information about the company and gaining local customers. Only Urban Craft and Douro Wines felt that the Facebook page should manage the effects of negative WOM responses (Table 2).

The objectives of the Facebook site also varied among the different firms but each firm appeared to have a developed strategy based on the type of firm and desired outcome of Facebook interaction (Table 3).

The outcomes of site ownership varied among the firms and three of the four met either increased sales or membership results. Table 4 depicts the reported benefits to the different firms coming from their Facebook page.

\section{CONCLUSIONS}

When the objectives of the different company Facebook pages were analyzed it was determined that only ACIAB had the objective of organizing member events, which is consistent with its mission. All firms reported that the site should engage consumers in dialog and be part of the company communication strategy. Braga Hostel, Urban Craft, and Douro Wines stated that the site should act to find ways to understand the consumer profile and only Braga Hostel desired the site to further consumer relationship. It is worthwhile to note that two firms wanted to use the Facebook site to better understand the profile and desires of the consumer. When Urban Craft asked consumers about a product preference, consumers responded they liked the color of a product that had the least sales. Although only a single case, this highlights drawbacks of taking consumer responses at face value. Such contradictions are frequent and recalls the famous Coke survey in which thousands of consumers reported a preference for "new Coke" but when the firm introduced the product it was found that consumers rebelled, demanding the reinstitution of their Coke Classic (see Table 3).

The Facebook strategy of the different firms, as well as their different objectives, was reflected in the varied reported benefits of the company Facebook page. Three firms (excluding Braga Hostel) noted increased knowledge about the company, which indicates the "Facebook effect" of Braga Pop Hostel may not be as effective as the others, but Braga Hostel 
found the site increased traffic. The only common benefit of four companies in the case research is the increased traffic on the company's Facebook page. Only in one case (Braga Pop Hostel) was Facebook selected as a channel of choice for establishing relationships with customers because this media allowed the company to interact with the client in a unique way of immediacy and interactivity that no another channel provided. This was consistent with ACIAB's object to increase membership and awareness of their offerings and the site did increase the number of clients. As a membership organization they would not be involved in sales; however, the significant traffic on ACIAB's website seemed to successfully lead to the wider customer basis, as well as the better company acknowledgment. Determined by ACIAB's business model, which targets customers directly, the number of clients is much more essential than sales volume.

Braga Hostel did increase brand loyalty and traffic but this did not translate into increased sales. Both Urban Craft and Douro Wines increased knowledge, traffic, and sales. What appears to be the case with these two firms was that the increased sales came from different customer sources. In the case of Urban Craft, who saw increased client number, sales came from existing and new consumers. Actually, injecting energy in either reaching out for new or keeping existing clients can be extremely acceptable and help a small or middle-size company to expand. In the case of Douro Wines, however, there was not an increase in new clients, pointing to the increase in sales to come from existing consumers buying more products (see Table 4).

For the first formulated hypothesis--H1: Small medium enterprises will benefit from the impact of WOM on social networks--the results suggest these firms can benefit from the impact of WOM on social networks. WOM presents itself as a prominent factor for the Facebook users to learn about companies and their products through the sharing of information and the interaction that the site enables. It must also be taken into consideration that the sites may generate negative communications about a firm that must be taken into account, making it necessary for firms to monitor the sites carefully. It was suggested that when WOM is negative it can be minimized if the content was taken from pages quickly and/or responded to effectively.

In consideration of H2: Social networks are an important means of enabling consumers to share information about a product/service, the results suggest that Facebook is a privilege channel for consumers to talk about brands and their products and services. Companies can accentuate this trend by promoting interaction between consumers and the firm through such activities as contests and sweepstakes on its pages. Such actions would have the objective of increasing the number of visitors interacting with the site.

Results concerning the third hypothesis, H3: The level of communication in social networks reflect the quality of the relationship that companies have with consumers indicate that each of the selected 
companies communicated on Facebook in a structured way in order to convey the brand values clearly.

In regard to H4: The presence of small medium enterprises in social networks will have a direct impact on the brand familiarity of these firms to the consumer, the results indicated that Facebook plays a crucial role in promoting the brand in online environments and is responsible for the increased knowledge about the firm and its products/offerings.

An analysis of the final hypothesis-H5: The direct contact with consumers through social networks generates greater involvement resulting in a direct impact on brand loyalty intentions suggests that Facebook leads to greater involvement with the brand and increases loyalty as evidenced through increased sales and increased customers.

Thus, and given the above, regarding the main research question How do social networks have impact in the management of Small Medium Enterprises?, the results indicate that, in particular, Facebook is an important channel that enables small and medium-sized companies to advertise their brands easily and accessibly without requiringlarge budgets. Similarly, this tool allows companies to communicate with consumers and establish a relationship with them that will prove crucial for a greater involvement and increased loyalty with the brand.

The study demonstrated that Facebook is a medium that facilitates and expands communication with the consumer of small or medium- sized firms. Working in an interactive environment and having tools that allow rapid conversation between all parties, Facebook presents itself as a unique environment that can enable businesses to increase prospective clients and also offer current consumers a closer relationship with the company. As such, the study seemed to indicate that presence on social networks can have an important role in both relationship development and increased sales/ membership. It is noted that when companies promoted the firm in a creative way that enabled consumers to interact with content (e.g., photographs, texts, contests, sweepstakes, or promotions) consumers were more likely to engage with the company and promote their products through WOM. The diverse range of firms and objectives of the study demonstrated that Facebook can be a useful, inexpensive, and dynamic part of a small or medium-size firm's business strategy. To do so, however, requires insight, focus, a well-developed Facebook plan, an understanding of analytics and the courage to engage the consumer in a meaningful, open manner.

\section{REFERENCES}

Becker, K., Nobre, H., \& Vijay, K. (2013). Monitoring and protecting company and brand reputation on social networks: When sites are not enough. Global Business and Economics Review, 15(2/3), 293-230. 
Bloemer, J. M. M. \& Kasper, H. D. P. (1994). The impact of satisfaction on brand loyalty: Urging on classifying satisfaction and brand loyalty. Journal of Consumer Satisfaction, Dissatisfaction and Complaining Behavior, 7, 152-160.

Brown, J. J. \& Reingen, P. H. (1987). Social ties and word-of-mouth referral behavior. Journal of Consumer Research, 14(3), 350-362.

Burson-Marsteller. (2010). The global social media check-up insights from the BursonMarsteller evidence-based communications roup. Retrieved from http://www. bursonmarsteller.com/Innovation_and_insights/blogs_and_podcasts/BM_Blog/ Documents/Burson-Marsteller\%202010\%20Global\%20Social\%20Media\%20Checkup\%20white\%20paper.pdf

Carson, D., Gilmore, A., Perry, C., \& Gronhaug, K. (2001). Qualitative marketing research. London, UK: Sage.

Deloitte. (2012). Measuring Facebook's economic impact in Europe Final Report (January 2012). Retrieved from http://www.deloitte.com/assets/Dcom UnitedKingdom/Local\%20Assets/Documents/Industries/TMT/uk-tmt-media-face book-europe-economic-impact.pdf

Facebook. (2013). World of mouth marketing. Retrieved from http://www.facebook. com/pages/World-of-MouthMarketing/146462498731131?v=app_7146470109

Gil-Or, O. (2010). The potential of Facebook in creating commercial value for service companies. Advances in Management, 3(2), 20-25.

Graham, J. \& Havlena, W. (2007). Finding the missing link: Advertising's impact on word of mouth, web searches, and site visits. Journal of Advertising Research, 47, 427-435.

Grönroos, C. (2001). Service management and marketing: A customer relationship management approach (2nd ed.). West Sussex, UK: Wiley.

Hennig-Thurau, H. T., Malthouse, E. C., Friege, C., Gensler, S., Lobschat, L., Rangaswamy, A., \& Skiera, B. (2010). The impact of new media on customer relationships. Journal of Service Research, 13(3), 311-330.

Hyllegard, K. H., Ogle, J. P., Yan, R., \& Reitz, A. R. (2011). An exploratory study of college students' fanning behavior on Facebook. College Student Journal, 45(3), 601-616.

Kaplan, A. M. \& Haenlein, M. (2010). Users of the world, unite! The challenges and opportunities of social media. Kelley School of Business, Indiana University, Business Horizons, 53, 59-68.

Keller, K. L. (1993). Conceptualization, measuring and managing customer-based brand equity. Journal of Marketing, 5(1), 1-22.

McKeefery, K. (2008). Online exclusive: Facebook pages offer brands a powerful presence. Direct Marketing News. Retrieved from http://www.dmnews.com/ online-exclusive-facebook-pages-offer-brands-a-powerful-presence/article/ $112875 /$

Neale, P., Thapa, S., \& Boyce, C. (2006). Preparing a case study: A guide for designing and conducting a case study for evaluation input. Retrieved from http://www2.pathfinder.org/site/DocServer/m_e_tool_series_case_study.pdf

Papacharissi, Z. (2009). The virtual geographies of social networks: A comparative analysis of Facebook, LinkedIn and ASmallWorld. New media $E$ society. Retrieved from http://tigger.uic.edu/ zizi/Site/Research_files/VirtualGeographies Facebook.pdf 
Reinartz, W., Krafft, M., \& Hoyer, W. D. (2004). The customer relationship management process: Its measurement and impact on performance. Journal of Marketing Research, 41, 293-305.

Soares, A., Pinho, J., \& Nobre, H. (2012). From social to marketing interactions: The role of social networks. Journal of Transnational Management, 17(2), 45-62.

Social Backers. (2013). Portugal Facebook Statistics. Retrieved from http://www. socialbakers.com/facebook-statistics/portugal

Sunga, Y., Kima, Y., Kwona, O., \& Moona, J. (2010). An explorative study of Korean consumer participation in virtual brand communities in social network sites. Journal of Global Marketing, 23(5), 430-445.

Trusov, M., Bucklin, R. E., \& Pauwels, K. (2009). Effects of word-of-mouth versus traditional marketing: Findings from an Internet social networking site. Journal of Marketing, 73, 90-102.

Urde, M. (1999). Brand orientation: A mindset for building brands into strategic resources. Journal of Marketing Management, 15(13), 117-133.

Yin, R. K. (1994). Case study research: Design and methods (2nd ed.). Thousand Oaks, CA: Sage.

Yin, R. K. (2001). Estudo de Caso: Planejamento e Métodos [Case Study Research: Design and Methods] (2nd ed.). Porto Alegre, Brazil: Bookman.

Zhang, J. (2010). To play or not to play: An exploratory content analysis of branded entertainment in Facebook. American Journal of Business, 25(1), 53-64. 